\title{
EFFECTS OF SALINITY ON OXYGEN CONSUMPTION AND BLOOD PROPERTIES OF YOUNG GREY MULLETS Mugil cephalus
}

\author{
Vitas Atmadi Prakoso"), Ki Tae Kim"', Byung Hwa Min" ${ }^{n+m}$, Rudhy Gustiano"), and Young Jin Chang") \\ ") Institute for Freshwater Aquaculture Research and Development \\ ") Department of Marine Bio-materials and Aquaculture, Pukyong National University, Korea \\ $\rightarrow$ National Fisheries Research and Development Institute, Korea
}

(Received 9 July 2015; Final revised 6 October 2015; Accepted 10 November 2015)

\begin{abstract}
Oxygen consumption (OC) is one of important factors in aquaculture activities, as the oxygen is a vital condition for all the organisms living in the water and having an aerobic type of respiration. OC is the preferred method for measuring and reporting the metabolic rate in fish. The aims of this study were to evaluate the effects of salinity on $\mathrm{OC}$ and blood properties of grey mullets. Five experimental groups were conducted to measure OC and blood properties of grey mullets Mugil cephalus (BW: $187.9 \pm 45.8 \mathrm{~g}$ ) according to salinity $(30 \rightarrow 0$ psu, $0 \rightarrow 30$ psu) changes; SDS: fish reared in seawater (SW, 30 psu) directly shifted to SW, SGF: SW fish gradually shifted to freshwater (FW, 0 psu), SDF: SW fish directly shifted to FW, FDF: FW fish directly shifted to FW, and FDS: FW fish directly shifted to SW. The result showed that OC tended to decrease in the groups of SW fish shifted to FW showing $194.5 \mathrm{mg} \mathrm{O} / \mathrm{kg} / \mathrm{h}$ at $25^{\circ} \mathrm{C}$ in SDS to 82.4 $\mathrm{mg} \mathrm{O} / \mathrm{kg} / \mathrm{h}$ at $15^{\circ} \mathrm{C}$ in SGF. On the contrary, OC increased in the groups of FW fish shifted to SW showing $80.5 \mathrm{mg} \mathrm{O} / \mathrm{kg} / \mathrm{h}$ at $15^{\circ} \mathrm{C}$ in FDF to $184.0 \mathrm{mg} \mathrm{O} / \mathrm{kg} / \mathrm{h}$ at $25^{\circ} \mathrm{C}$ in FDS. Cortisol levels at the end of experiments were rapidly increased with the lowering salinities in SW fish shifted to FW showing $20.6 \mathrm{ng} / \mathrm{mL}$ in SDS to $316.2 \mathrm{ng} / \mathrm{mL}$ in SDF, while those were decreased with the increasing salinities in FW fish shifted to SW showing $40.2 \mathrm{ng} / \mathrm{mL}$ in FDF to $10.3 \mathrm{ng} / \mathrm{mL}$ in FDS. However, glucose levels showed no significant differences among all experimental groups. Based on the information from this study, aquaculture of grey mullet might be applied or developed in freshwater due to its osmotic adaptation ability.
\end{abstract}

KEYWORDS: grey mullet, salinity, oxygen consumption, blood properties

\section{INTRODUCTION}

Oxygen consumption $(\mathrm{OC})$ is one of a vital parameter for all the organisms living in the water and having an aerobic type of respiration. OC is the preferred method for measuring and reporting the metabolic rate in fish. OC rate by fish is useful in determining carrying capacity of fish in culture system and in predicting aeration needs and flow rates in various aquaculture environments (Lovell, 1998).

The researches on OC were continuously developed for aquaculture benefit, not only on freshwater species but also marine species (Kim et al., 1995; Lyytikainen \& Jobling, 1998; Jeong et al., 2007). Many authors investigated about the effects of various factors on $\mathrm{OC}$ of fish, such as: temperature (Franklin et

\# Correspondence: Institute for Freshwater Aquaculture Research and Development. Jl. Sempur No. 1, Bogor 16154 , Indonesia. Phone: + (0251) 8313200

E-mail:vitas.atmadi@gmail.com al., 1995; Wares \& Igram, 1979; Requena et al., 1997; Van Maaren et al., 2000; Turker, 2011), salinity (Tsuzuki et al., 2008; Iwama et al., 1997), photoperiod (Chang et al., 2005), and rearing density (Szczepkowski et al., 2011; Bjornsson \& Olafsdottir, 2006; Duan et al., 2011).

Related with salinities, grey mullet Mugil cephalus is one of interesting species to be observed for aquaculture development, especially for freshwater aquaculture development. Grey mullet is a good osmoregulator species which can be found in coastal marine, brackish waters, and freshwater. They move between marine and freshwater environments of rivers and flooded rice fields (Saleh, 2008). Therefore, basic information on OC and blood properties of grey mullets is needed for development of grey mullets' freshwater aquaculture. The aims of this study were to evaluate the effects of salinity on $\mathrm{OC}$ and blood properties of grey mullets. 


\section{MATERIALS AND METHODS}

Thirty one grey mullets Mugil cephalus (TL: $27.3 \pm$ $2.1 \mathrm{~cm}$, BW: $187.9 \pm 45.8 \mathrm{~g}$ ) which were collected from Suncheon Bay and reared in culture tanks were used for the experiments. Before the experiments, grey mullets were divided and acclimated into two different rearing environments, which were seawater $(\mathrm{SW})$ and freshwater $(\mathrm{FW})$. The fish were reared in recirculating tanks and fed two times a day at $2 \%$ of their body weight with commercial feed. No food was given to any experimental fish for 24 hours until experiments.

Five experiments were divided into two groups, the groups of SW fish shifted to FW (SDS, SGF, and SDF), and the groups of FW fish shifted to SW (FDF and FDS). SDS: fish reared in SW directly transferred to SW, SGF: fish reared in SW gradually transferred to FW, SDF: fish reared in SW directly transferred to FW, FDF: fish reared in FW directly transferred to FW, FDS: fish reared in FW directly transferred to SW.

The experiments were conducted to observe the effect of different salinity level on OC of grey mullets, from 0 psu (Practical Salinity Unit) up to $30 \mathrm{psu}$ (Table 1). In each experiment, acclimation to exact salinity level was carried out 2 days before fish OC measurement in respiratory chamber running for six days, except in SDF (direct transfer without acclimation).

To measure the OC according to salinity and temperature changes, OC measurement system and OC calculation methods were adapted to Chang et al. (2005). Three grey mullets were put into respiratory chamber $($ dimension $=20 \mathrm{~cm} \times 30 \mathrm{~cm} \times 20 \mathrm{~cm})$ inside the closed recirculating system with photope- riod of 12 hours light (07:00-19:00) : 12 hours dark (19:00-07:00). DO of inflow water was maintained above $7.0 \mathrm{mg} / \mathrm{L}$ in each experiment. During experiment, water temperature inside the $\mathrm{OC}$ measurement system was increased slowly from $15^{\circ} \mathrm{C}$ to the target temperature $\left(15^{\circ} \mathrm{C}, 20 \mathrm{C}\right.$, and $\left.25^{\circ} \mathrm{C}\right)$ at a rate of $0.5^{\circ} \mathrm{C} /$ $\mathrm{h}$ to minimize any thermal shock to the fish.

In addition to measuring the $\mathrm{OC}$, the behavior of the fish was observed during experiments, including their movements in the water and breathing frequency per minute. Behavioral index was used to evaluate the fish activity in each experiment inside the respiratory chamber (Table 2). At the end of each experiment of OC measurement according to salinity and temperature changes, blood samples were collected from three grey mullets from respiratory chamber (Exp.) and three grey mullets from rearing tank (Con.). In lethal DO experiments, blood samples were collected from three of five fish just after the fish died. Fish were anesthetized using 2-phenoxyethanol and blood samples were collected using heparinized syringes, centrifuged $(12,000 \mathrm{rpm}, 5 \mathrm{~min}$.), and stored in deep freezer until analyzing blood properties of hemoglobin $(\mathrm{Hb})$ and hematocrit $(\mathrm{Ht})$ as the oxygen binding factor. $\mathrm{Na}^{+}, \mathrm{K}^{+}, \mathrm{Cl}^{-}, \mathrm{Ca}, \mathrm{Mg}$, and osmolality as the osmoregulation factor. Furthermore, cortisol, glucose, and total protein were analyzed for the stress factor. Hematocrit $(\mathrm{Ht})$ was analyzed by using microhematocrit reader (Micro Hematocrit Reader, Hawksley). Hemoglobin ( $\mathrm{Hb}), \mathrm{Na}^{+}, \mathrm{K}^{+}, \mathrm{Cl}^{-}, \mathrm{Ca}, \mathrm{Mg}$, glucose, and total protein were analyzed by using Chemical Analyzer (Fujifilm Dri-Chem 3500i, Japan). Plasma cortisol was analyzed by Enzyme Immonoassay (EIA) using Cortisol EIA kit (Oxford Biomedical Research, USA). Plasma osmolality was examined with Vapor Pressure Osmometer (Vapro 5520; Wescor Co., USA).

Table 1. Experimental conditions in OC measurement

\begin{tabular}{cccccc}
\hline Exp. & $\begin{array}{c}\text { Water } \\
\text { temperature } \\
\text { change }\left({ }^{\circ} \mathbf{C}\right)\end{array}$ & $\begin{array}{c}\text { Salinity } \\
\text { change } \\
(\mathbf{p s u})\end{array}$ & $\begin{array}{c}\text { Total } \\
\text { length } \\
\mathbf{( \mathbf { c m } )}\end{array}$ & $\begin{array}{c}\text { Body } \\
\text { weight } \\
\mathbf{( g )}\end{array}$ & $\begin{array}{c}\text { No. } \\
\text { of fish }\end{array}$ \\
\hline SDS & $15 \rightarrow 20 \rightarrow 25$ & $30 \rightarrow 30$ & $26.4 \pm 1.1$ & $176.0 \pm 18.4$ & 3 \\
SGF & $15 \rightarrow 20 \rightarrow 25$ & $30 \rightarrow 10 \rightarrow 0$ & $25.5 \pm 0.9$ & $157.3 \pm 19.4$ & 3 \\
SDF & $15 \rightarrow 20 \rightarrow 25$ & $30 \rightarrow 0$ & $28.4 \pm 1.6$ & $228.0 \pm 58.6$ & 3 \\
FDF & $15 \rightarrow 20 \rightarrow 25$ & $0 \rightarrow 0$ & $28.3 \pm 0.9$ & $197.0 \pm 14.1$ & 3 \\
FDS & $15 \rightarrow 20 \rightarrow 25$ & $0 \rightarrow 30$ & $29.0 \pm 0.9$ & $221.3 \pm 20.6$ & 3 \\
\hline
\end{tabular}

Note: SDS: fish reared in SW directly transferred to SW, SGF : fish reared in SW gradually transferred to FW, SDF : fish reared in SW directly transferred to FW, FDF : fish reared in FW directly transferred to FW, FDS : fish reared in FW directly transferred to SW. 
Table 2. Behavioral indices of fish in experiments of OC and lethal DO

\begin{tabular}{clc}
\hline Index & \multicolumn{1}{c}{ Movement } & Breath freq./min. \\
\hline I & Active swimming & $>110$ \\
II & Moderate swimming & $81-110$ \\
III & Slow swimming & $51-80$ \\
IV & Very slow swimming & $31-50$ \\
V & Lost balance, no movement & $1-30$ \\
VI & Died & 0 \\
\hline
\end{tabular}

The data were analyzed by using PASW Statistics 18 software. One-way ANOVA was conducted to analyze OC and physio-chemical properties of blood according to different salinity experiment, two-way ANOVA was conducted to analyze the interaction between salinity and temperature on OC. and $t$-test was conducted to analyze the differences of OC according to different photoperiod and compare the physio-chemical properties of blood between control and experiment.

\section{RESULTS AND DISCUSSION}

\section{Oxygen Consumption According To Salinity}

The grey mullets from the groups of SW fish shifted to FW and the groups of FW fish shifted to SW showed various rhythm in closed recirculating system at each water temperature from the continuous OC measurements with stepwise rising temperature from $15^{\circ} \mathrm{C}$ to $25^{\circ} \mathrm{C}$. As shown in Figure 1 and 2 , the changes in $\mathrm{OC}$ with water temperature for each experiment showed a linear increase in line with water temperature, except the SDF. The OC of grey mullets which determined every hour clearly showed various type of OC fluctuations. Sudden increase of OC occured in each experiment during the beginning of light period and dark period with the various amount in each experiment.

The OC of grey mullets in SDS during the light period was higher than dark period at each temperature (Figure 1). Same patterns with SDS were also found in SDF and SGF, while grey mullets in FDF showed a reversed day/night $\mathrm{OC}$ rhythm and consumed less oxygen during the day period. The behavioral change also occured in FDS. In FDS, the grey mullets shifted to consume oxygen higher in light period start from $20^{\circ} \mathrm{C}$.

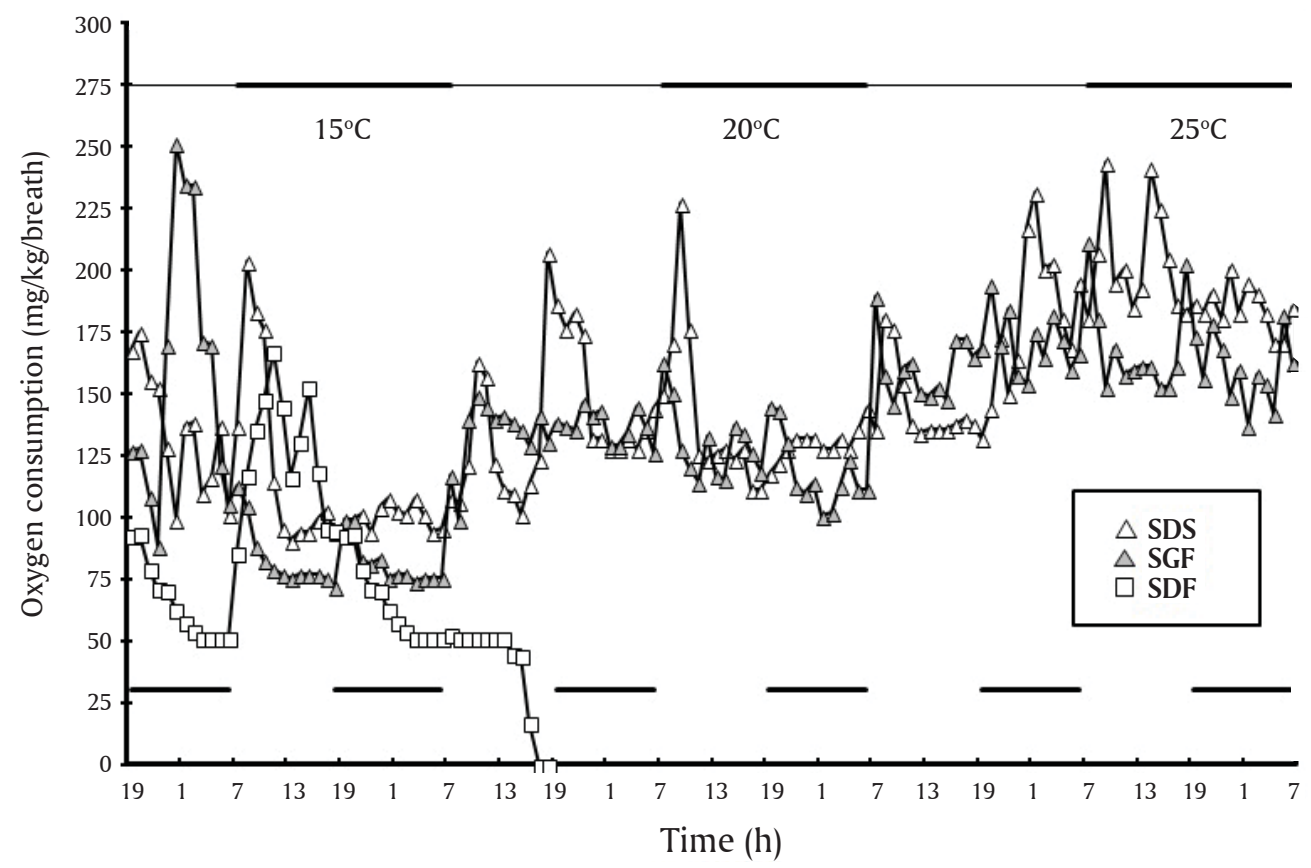

Figure 1. OC of grey mullets Mugil cephalus by water temperature in the groups of SW fish shifted to FW; SDS, SGF, and SDF are the same abbreviations as shown in Table 1 
In the groups of SW fish shifted to FW, grey mullets consumed $112.4,136.0$, and $194.5 \mathrm{mg} \mathrm{O} / \mathrm{kg} / \mathrm{h}$ at $15^{\circ} \mathrm{C}, 20^{\circ} \mathrm{C}$, and $25^{\circ} \mathrm{C}$, respectively in SDS, showing a linear increase in $\mathrm{OC}$ with water temperature, which was significantly different at each temperature $(\mathrm{P}<0.05)$. In SGF, grey mullets acclimated in freshwater by gradual salinity change consumed lower amount of oxygen compare to SDS in each temperature. The value was $82.4,124.1,164.6 \mathrm{mg} \mathrm{O} / \mathrm{kg} / \mathrm{h}$ at $15^{\circ} \mathrm{C}, 20^{\circ} \mathrm{C}$, and $25^{\circ} \mathrm{C}$, respectively $(\mathrm{P}<0.05)$. These values were also lower compare to FDF and FDS, showing clearly different response due to the different salinity. Another result showed that grey mullets consumed 95.5 $\mathrm{mg} \mathrm{O}_{2} / \mathrm{kg} / \mathrm{h}$ at $15^{\circ} \mathrm{C}$ in SDF. Meanwhile, OC data from
SDF experiment during $20^{\circ} \mathrm{C}$ and $25^{\circ} \mathrm{C}$ cannot be observed due to fish mortality during experiment caused by the effect of abrupt salinity changes from SW to FW (Table 3).

OC of fish increased linearly with the temperature rise in this study. The OC of fish reflected the activity of fish itself (Beamish \& Mookherjii, 1964). This seems in this present study the activity of fish including their breath frequency increased by the rising of temperature.

The grey mullets in SDS showed that the energy demand of grey mullets reared in seawater elevated on active at the morning. This result was opposite

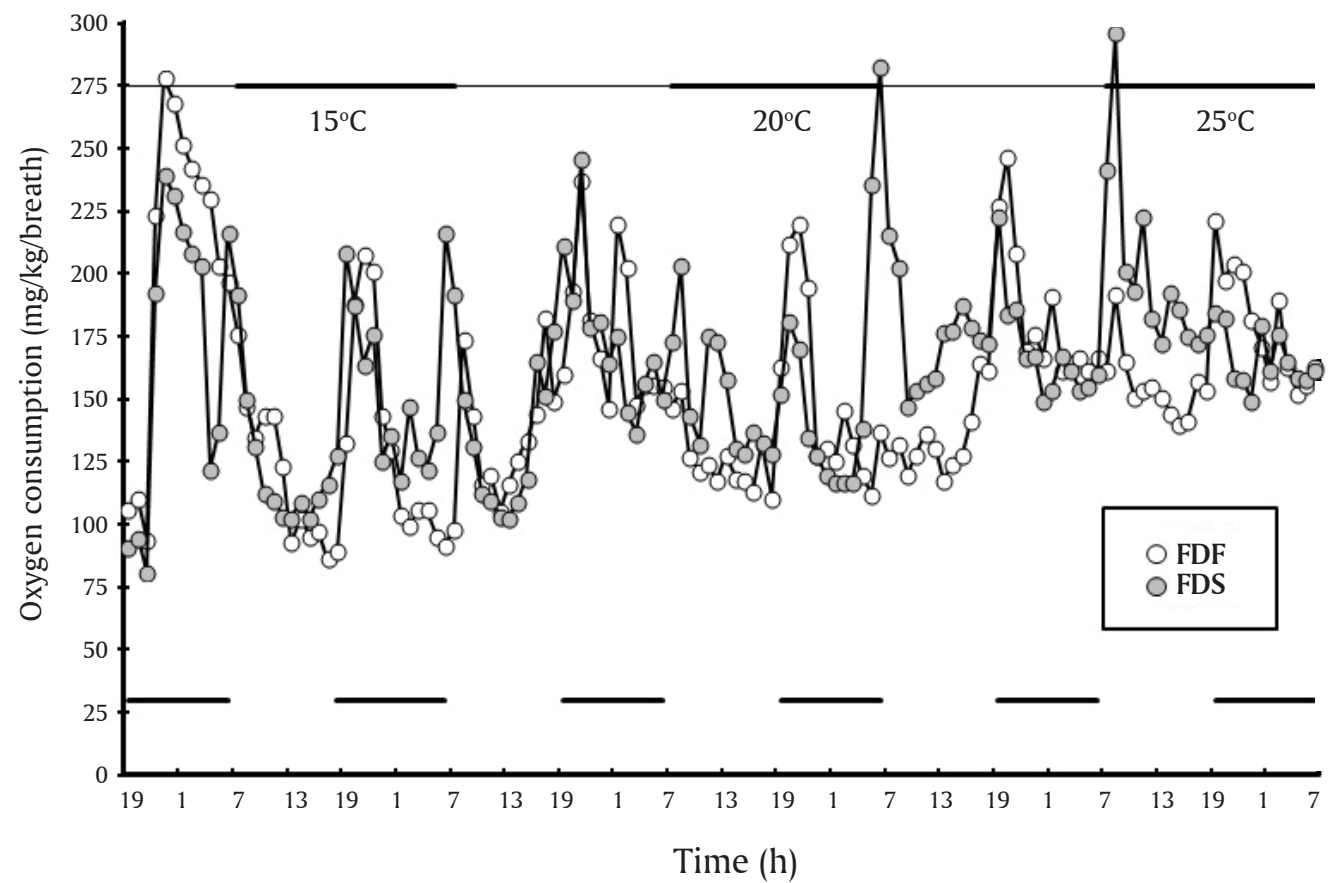

Figure 2. OC of grey mullets Mugil cephalus by water temperature in the groups of FW fish shifted to SW; FDF and FDS are the same abbreviations as shown in Table 1

Table 3. Average $\mathrm{OC}\left(\mathrm{mg} \mathrm{O}_{2} / \mathrm{kg} / \mathrm{h}\right)$ of grey mullets Mugil cephalus in each experiment

\begin{tabular}{|c|c|c|c|c|c|c|}
\hline \multirow{2}{*}{ Group } & \multicolumn{3}{|c|}{ Water temperature $\left({ }^{\circ} \mathrm{C}\right)$} & & \multirow{2}{*}{$a$} & \multirow{2}{*}{$r^{2}$} \\
\hline & 15 & 20 & 25 & & & \\
\hline SDS & $112.4 \pm 31.0^{\mathrm{a}^{\mathrm{um}}}$ & $136.0 \pm 24.8^{\mathrm{b}^{\mathrm{bm}}}$ & $194.5 \pm 19.1^{\mathrm{c}^{* m *}}$ & 8.21 & -16.59 & 0.621 \\
\hline SGF & $82.4 \pm 10.8^{\mathrm{a}^{4}}$ & $124.1 \pm 15.6^{\mathrm{b}^{*}}$ & $164.6 \pm 17.2^{\mathrm{c}^{*}}$ & 8.22 & -40.72 & 0.843 \\
\hline SDF & $95.5 \pm 37.1^{*}$ & - & - & - & & - \\
\hline FDF & $126.8 \pm 36.5^{\mathrm{a}^{\mathrm{an}}}$ & $139.1 \pm 30.3^{\mathrm{a}^{\mathrm{atw}}}$ & $167.9 \pm 22.2^{\mathrm{b}^{\mathrm{w}}}$ & 4.11 & 62.43 & 0.239 \\
\hline FDS & $139.2 \pm 34.4^{\mathrm{a}^{\mathrm{we}}}$ & 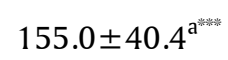 & $184.0 \pm 32.0^{\mathrm{b}^{* *}}$ & 4.48 & 69.78 & 0.213 \\
\hline
\end{tabular}

Note: All abbreviations are the same as shown in Table 1. Each values represent means \pm SD $(n=24)$. Different letters indicate significant differences between water temperatures in each experiment, respectively. Asterisks indicate significant differences within groups of seawater to freshwater and within the groups of FW fish shifted to SW $(\mathrm{P}<0.05$, one-way ANOVA) 
to FDF where grey mullets reared was active at night. Another pattern occured in some experimental groups, which was slightly different. The OC behavior shifted from consumed lower amount at dark period to lower amount at light period or the vice versa. Lyytikäinen \& Jobling (1998) concluded that daily variations in OC had an influence on the water requirements of fish in aquaculture, water requirements should be estimated according to peak OC rates rather than the daily average $\mathrm{OC}$.

OC tended to decrease in the groups of SW fish shifted to FW showing the highest value of $194.5 \mathrm{mg}$ $\mathrm{O}_{2} / \mathrm{kg} / \mathrm{h}$ at $25^{\circ} \mathrm{C}$ in SDS and the lowest value of 82.4 $\mathrm{mg} \mathrm{O}_{2} / \mathrm{kg} / \mathrm{h}$ at $15^{\circ} \mathrm{C}$ in SGF. On the contrary, OC increased in the groups of FW fish shifted to SW showing the highest value of $184.0 \mathrm{mg} \mathrm{O} / \mathrm{kg} / \mathrm{h}$ at $25^{\circ} \mathrm{C}$ in FDS.

A two-way ANOVA was conducted that examined the effect of salinity and temperature on OC. There was a significant interaction between the effects of salinity and temperature on OC within the groups of FW fish shifted to SW, while the interaction between the effects of salinity and temperature within the groups of SW fish shifted to FW was not significant ( $\mathrm{P} \geq 0.05)$ (Table 4).

The fish in each experiment showed various pattern on OC according to salinity in both of group during light and dark period. In the groups of SW fish shifted to FW, the average of OC in SDS during the dark period was $81.2 \%, 91.5 \%$, and $90.7 \%$ lower than light period at $15^{\circ} \mathrm{C}, 20^{\circ} \mathrm{C}$, and $25^{\circ} \mathrm{C}$, respectively. Same pattern was found in SGF and SDF. In SGF, the average of OC during the dark period was $97.8 \%$, $90.9 \%$, and $95.0 \%$ lower than light period at $15^{\circ} \mathrm{C}, 20^{\circ} \mathrm{C}$, and $25^{\circ} \mathrm{C}$, respectively. Meanwhile, the average of $\mathrm{OC}$ in SDF during the dark period was $51.2 \%$ lower than light period only at $15^{\circ} \mathrm{C}$. There was no record of OC at $20^{\circ} \mathrm{C}$ and $25^{\circ} \mathrm{C}$ due to fish mortality.

In the groups of FW fish shifted to SW, another different pattern was found in FDF, the average of OC during the dark period in FDF was $111.9 \%, 120.6 \%$, and $115.7 \%$ higher than light period at $15 \mathrm{C}, 20 \mathrm{C}$, and $25^{\circ} \mathrm{C}$, respectively. Which means the OC pattern was all higher in dark period than light period. Meanwhile, the average of OC in FDS during the dark period was $127.0 \%$ and $104.1 \%$ higher than light period at $15^{\circ} \mathrm{C}$ and $20^{\circ} \mathrm{C}$, and it was $82.7 \%$ lower than light period at $25^{\circ} \mathrm{C}$. The change of tendency on OC due to salinity changes during light and dark period was found in these experiments (Table 5).

The slope (b) of linear regression in the groups of SW fish shifted to FW during the light period was significantly higher than that of the groups of FW fish shifted to SW. Same pattern was also occured during the dark period. The slope (b) of linear regression in the groups of SW fish shifted to FW during the dark period was significantly higher than that of the groups of FW fish shifted to SW. These conditions indicated that increment of OC of grey mullets were faster in the groups of SW fish shifted to FW than the groups of FW fish shifted to SW (Table 5).

Increasing or decreasing of OC clearly related with salinity changes due to stress response reflecting in immune-related parameters. It caused physiological disturbances and change photoperiodical activity and metabolism of fish. Fish mortality could be occured by the abrupt salinity changes from seawater to freshwater. In contrary, Arnason et al. (2013) on Atlantic cod Gadus morhua that were reared in salinity and abrupt salinity changes have limited or no effects on stress and immune-related parameters, and there were no indications of ion regulatory disturbances at low salinities. Meanwhile, the effect of salinity change from freshwater to seawater will not cause the mortality due to grey mullets' osmoregulation ability to tolerate seawater as its natural habitat.

\section{Fish Behavior and Breath Frequency}

As shown in Table 6, the fish in each experiment showed six subsequent responses based on their swimming activity and breath frequency. All experimental groups were in normal behavior during experiments, showing stable activities with behavioral index from I to III, except for SDF. SDF showed abnormal behavior with index from IV to VI because of abrupt salinity change. The highest index was found in SDS, SGF, and FDS, while the lowest index was found in SDF.

Table 4. P-values from two-way ANOVA of OC in grey mullets Mugil cephalus at the end of experiments

\begin{tabular}{cccc}
\hline Group & Temperature $\left({ }^{\circ} \mathrm{C}\right)$ & Salinity (\%) & Temperature $\left({ }^{\circ} \mathrm{C}\right)$ x Salinity (\%) \\
\hline SW fish shifted to FW & $<0.001$ & $<0.001$ & 0.064 \\
FW fish shifted to SW & $<0.001$ & $<0.001$ & 0.006 \\
\hline
\end{tabular}

Note: $\mathrm{SW}=$ seawater; $\mathrm{FW}=$ freshwater 
Table 5. Average $\mathrm{OC}(\mathrm{mg} \mathrm{O} / \mathrm{kg} / \mathrm{h})$ of grey mullets Mugil cephalus during light and dark periods in each experiment

\begin{tabular}{|c|c|c|c|c|c|c|c|}
\hline \multirow{2}{*}{ Group } & \multirow{2}{*}{$\mathrm{L}: \mathrm{D}$} & \multicolumn{3}{|c|}{ Water temperature $\left({ }^{\circ} \mathrm{C}\right)$} & \multirow{2}{*}{ b } & \multirow{2}{*}{ a } & \multirow{2}{*}{$r^{2}$} \\
\hline & & 15 & 20 & 25 & & & \\
\hline \multirow{2}{*}{ SDS } & $\mathrm{L}$ & $124.1 \pm 41.1^{\mathrm{a}}$ & $142.0 \pm 34.1^{\mathrm{a}}$ & $204.0 \pm 22.0^{\mathrm{b}}$ & 7,99 & -3.21 & 0.486 \\
\hline & $\mathrm{D}$ & $100.8 \pm 4.7^{7^{\mathrm{atw}}}$ & $130.0 \pm 6.7^{\mathrm{b}^{* \ldots}}$ & $185.1 \pm 8.9^{9^{* w}}$ & 8.43 & -29.97 & 0.936 \\
\hline \multirow{2}{*}{ SGF } & $\mathrm{L}$ & $83.3 \pm 12.8^{\mathrm{a}}$ & $130.0 \pm 14.9^{\mathrm{b}}$ & $168.8 \pm 19.8^{c}$ & 8.55 & -43.59 & 0.835 \\
\hline & $\mathrm{D}$ & $81.5 \pm 8.8 a^{*}$ & $118.2 \pm 14.6^{\mathrm{b}^{*}}$ & $160.4 \pm 13.9^{c}$ & 7.89 & -37.84 & 0.875 \\
\hline \multirow{2}{*}{ SDF } & $\mathrm{L}$ & $125.6 \pm 25.3^{\mathrm{a}}$ & - & - & - & - & - \\
\hline & $\mathrm{D}$ & 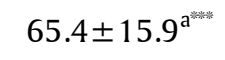 & - & - & - & - & - \\
\hline \multirow{2}{*}{ FDF } & $\mathrm{L}$ & $119.7 \pm 29.4^{\mathrm{a}=* *}$ & $126.1 \pm 13.0^{\mathrm{a}^{\text {we }}}$ & $155.7 \pm 13.8^{\mathrm{b}^{\mathrm{b} *}}$ & 3.61 & 61.70 & 0.350 \\
\hline & $\mathrm{D}$ & $134.0 \pm 42.6^{\mathrm{a}}$ & $152.1 \pm 37.2^{\mathrm{ab}}$ & $180.1 \pm 22.8^{\mathrm{b}}$ & 4.61 & 63.17 & 0.237 \\
\hline \multirow{2}{*}{ FDS } & $\mathrm{L}$ & $122.6 \pm 26.1^{\mathrm{a}}$ & $151.8 \pm 24.7^{\mathrm{b}}$ & $201.4 \pm 36.7^{c}$ & 7.88 & 1.08 & 0.555 \\
\hline & $\mathrm{D}$ & $155.7 \pm 34.6^{\mathrm{a}}$ & $158.1 \pm 52.8^{\mathrm{a}}$ & $166.5 \pm 11.6^{\mathrm{a}}$ & 1.08 & 138.49 & 0.015 \\
\hline
\end{tabular}

Note: All abbreviations are the same as shown in Table 1. Each values represent means \pm SD (n $=12$ ). Different letters indicate significant difference between water temperature in each experiment, respectively $(\mathrm{P}<0.05$, one-way ANOVA). Asterisk indicates significant difference between light and dark in each experiment, respectively ( ${ }^{*}: \mathrm{P}<0.05,{ }^{*}: \mathrm{P}<0.01$, ${ }^{*}{ }^{* * *}$ : $\mathrm{P}<0.001, t$-test)

The breath frequency of grey mullets from whole experiments at $15^{\circ} \mathrm{C}, 20^{\circ} \mathrm{C}$, and $25^{\circ} \mathrm{C}$ were shown in Figure 3. The slope of linear regression of breath frequency according to different water temperature in grey mullets from the groups of SW fish shifted to FW which consisting of SDS and SGF was 3.07 and 1.81 , respectively, while the slope of linear regression of breath frequency according to different water temperature in grey mullets from the groups of FW fish shifted to SW which consisting of FDF and FDS was 0.99 and 2.18, respectively. These values were indicating the breath frequency was higher at SW condition. The slope of linear regression of breath frequency from the results might be related with fish metabolism. Grey mullets had higher metabolic rates during SW rearing condition, while the result was vice versa during FW rearing condition. Morgan \&
Iwama (1991) suggested that low metabolic rates were the most often associated to the water salinity, which was in species that was commonly found and adapted at a particular life stage. This condition seems to be related with the natural environment of grey mullets. Grey mullets occured in seawater as their natural habitat. The grey mullets Mugil cephalus, migrates to feed, moving from seawater to brackish as it grew from fry to adult (Kim et al., 2004).

\section{Blood Properties}

The salinity change from SW to FW tended to decrease $\mathrm{Ht}$ and $\mathrm{Hb}$ values in the groups of SW fish shifted to FW. The highest value of $\mathrm{Ht}$ and $\mathrm{Hb}$ was $30.6 \%$ and $7.3 \mathrm{~g} / \mathrm{dL}$ in SDS, respectively. Whereas, $\mathrm{Ht}$ and $\mathrm{Hb}$ tended to increase in the groups of FW fish shifted to SW. The highest value of $\mathrm{Ht}$ and $\mathrm{Hb}$ was

Table 6. Behavioral indices of grey mullets Mugil cephalus in $\mathrm{OC}$ experiments

\begin{tabular}{cccccc}
\hline Exp. & Beginning & $\mathbf{1 5}^{\circ} \mathrm{C}$ & $\mathbf{2 0}^{\circ} \mathrm{C}$ & $\mathbf{2 5}^{\circ} \mathrm{C}$ & End \\
\hline SDS & I & II & II & I & I \\
SGF & II & II & II & I & I \\
SDF & IV & V & VI & - & - \\
FDF & II & II & II & II & II \\
FDS & II & II & I & I & I \\
\hline
\end{tabular}

Note: All abbreviations are the same as in Table 1 

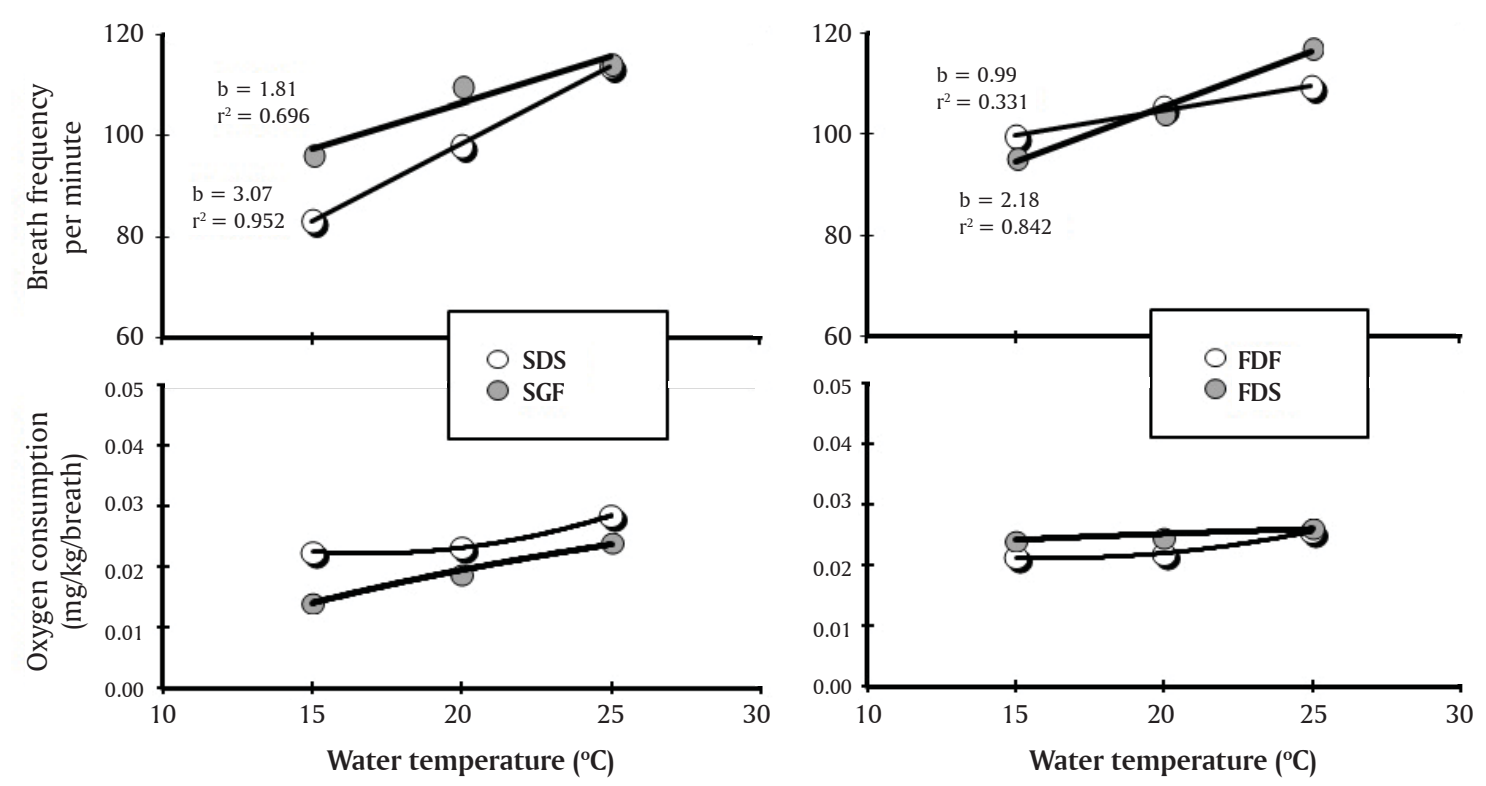

Figure 3. Breath frequency per minute and OC per breath in grey mullets Mugil cephalus from the groups of SW fish shifted to FW and the groups of FW fish shifted to SW; All abbreviations are the same as shown in Table 1

$47.9 \pm 0.2 \%$ and $8.5 \pm 0.6$ in FDS, respectively (Table 7).

$\mathrm{Na}^{+}$values were decreased within the groups of SW fish shifted to FW from $163.5 \mathrm{mEq} / \mathrm{L}$ in SDS to
$134.5 \mathrm{mEq} / \mathrm{L}$ in SDF, while those values were increased within groups of FW fish shifted to SW from 136.5 $\mathrm{mEq} / \mathrm{L}$ in $\mathrm{FDF}$ to $162.0 \mathrm{mEq} / \mathrm{L}$ in $\mathrm{FDS}$. $\mathrm{Cl}^{-}$and Ca values also showed the same pattern. $\mathrm{Cl}^{-}$values decreased showing $155.5 \mathrm{mEq} / \mathrm{L}$ in $\mathrm{SDS}$ to $134.5 \mathrm{mEq} / \mathrm{L}$ in $\mathrm{SDF}$,

Table 7. Physical properties of blood in grey mullets Mugil cephalus at the end of experiments

\begin{tabular}{|c|c|c|c|}
\hline \multirow{2}{*}{\multicolumn{2}{|c|}{ Group }} & \multicolumn{2}{|c|}{ Component } \\
\hline & & Ht (\%) & $\mathrm{Hb}(\mathrm{g} / \mathrm{dL})$ \\
\hline \multirow{2}{*}{ SDS } & Con. & $33.8 \pm 5.5$ & $8.5 \pm 0.5$ \\
\hline & Exp. & $30.6 \pm 10.2^{b}$ & $7.3 \pm 0.9^{b}$ \\
\hline \multirow{2}{*}{ SGF } & Con. & $37.1 \pm 3.0$ & $8.2 \pm 0.8$ \\
\hline & Exp. & $26.2 \pm 1.1^{\mathrm{b}^{\mathrm{b} *}}$ & $6.7 \pm 0.6^{b^{*}}$ \\
\hline \multirow{2}{*}{ SDF } & Con. & $30.2 \pm 4.9$ & $6.9 \pm 0.4$ \\
\hline & Exp. & $16.2 \pm 1.2^{\mathrm{a}^{* *}}$ & $4.2 \pm 1.0^{\mathrm{a}=}$ \\
\hline \multirow{2}{*}{ FDF } & Con. & $18.9 \pm 5.4$ & $4.4 \pm 0.8$ \\
\hline & Exp. & $26.8 \pm 0.2^{\mathrm{a}}$ & $5.8 \pm 1.1^{\mathrm{a}}$ \\
\hline \multirow{2}{*}{ FDS } & Con. & $22.8 \pm 5.4$ & $5.9 \pm 0.9^{*}$ \\
\hline & Exp. & $47.9 \pm 0.2^{c}$ & $8.5 \pm 0.6^{b}$ \\
\hline
\end{tabular}

Note: SDS, SGF, SDF, FDF, and FDS are the same abbreviations as shown in Table 1. Con: control, Exp: experimental fish, $\mathrm{Hb}$ : hemoglobin, Ht: hematocrit, Values are the mean \pm $\mathrm{SD}(\mathrm{n}=3)$. Different letters in each experiment indicate significant differences within the groups of SW fish shifted to FW and within the groups of FW fish shifted to SW $(\mathrm{P}<0.05$, one-way ANOVA). Asterisks indicate significant differences between Con. and Exp. in each experiment (":

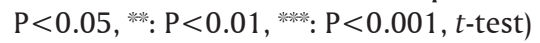




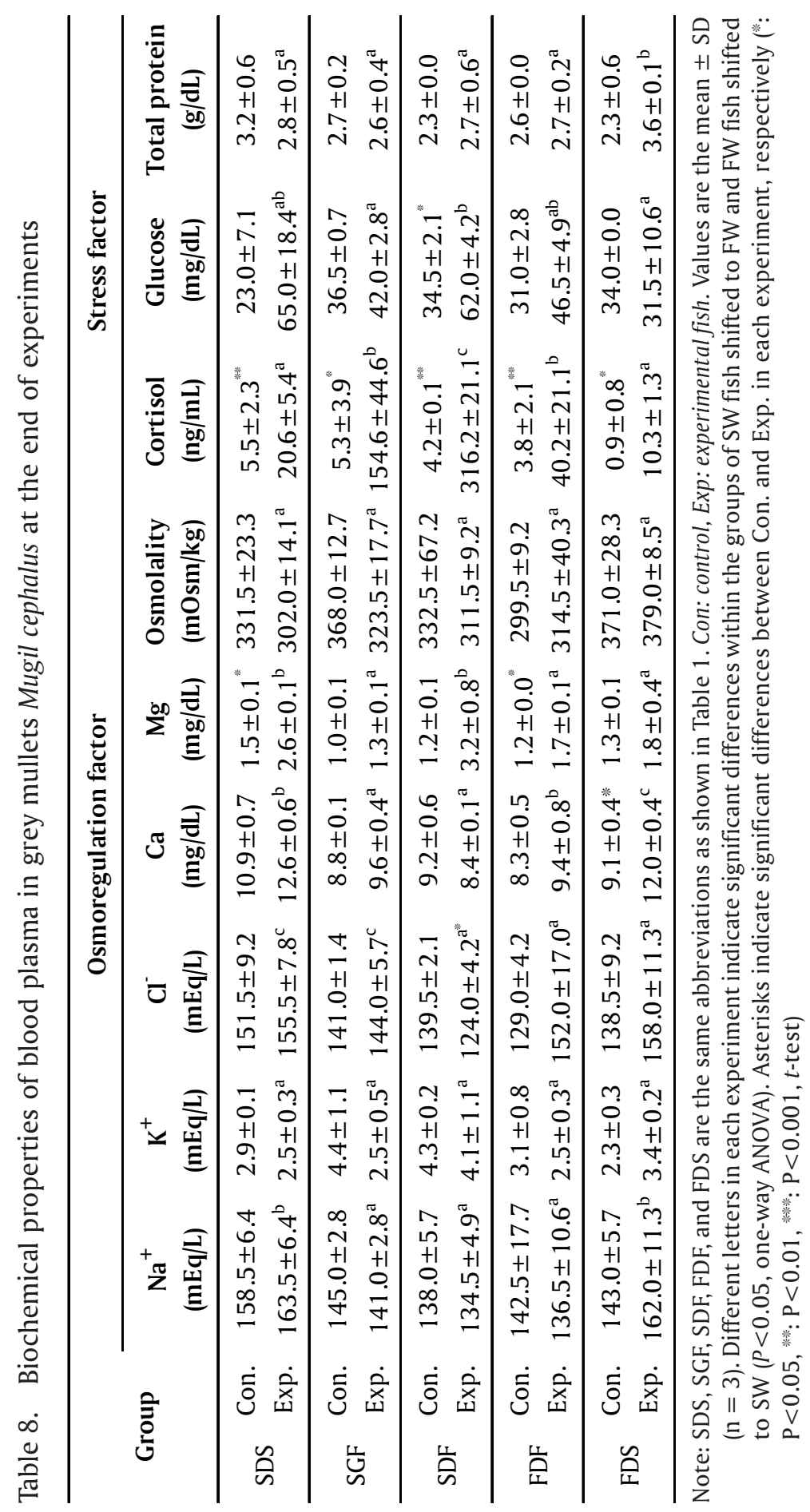


while those increased from $152.0 \mathrm{mEq} / \mathrm{L}$ in FDF to $158.0 \mathrm{mEq} / \mathrm{L}$ in FDS. Furthermore, Ca values decreased from $12.6 \mathrm{mg} / \mathrm{dL}$ in SDS to $8.4 \mathrm{mg} / \mathrm{dL}$ in SDF. Those increased from $9.4 \mathrm{mg} / \mathrm{dL}$ in FDF to $12.0 \mathrm{mg} / \mathrm{dL}$ in FDS. Other factors such as $\mathrm{K}^{+}$and osmolality were not significantly different. The highest value of $\mathrm{Mg}$ was found at $3.2 \mathrm{mg} / \mathrm{dL}$ in $\mathrm{SDF}$, and the lowest value was found at $1.3 \mathrm{mg} / \mathrm{dL}$ in $\mathrm{SGF}(\mathrm{P}<0.05)$ (Table 8).

Cortisol levels at the end of experiments increased with the lowering salinities in SW fish shifted to FW showing $20.6 \mathrm{ng} / \mathrm{mL}$ in SDS to $316.2 \mathrm{ng} / \mathrm{mL}$ in SDF, while those decreased with the increasing salinities in FW fish shifted to SW showing $40.2 \mathrm{ng} / \mathrm{mL}$ in FDF to $10.3 \mathrm{ng} / \mathrm{mL}$ in FDS. However, the glucose levels among all the experimental groups were not significantly different, while total protein values were different only in the groups of FW fish to SW with the highest value of $3.6 \mathrm{~g} / \mathrm{dL}$ in FDS, while the lowest value was $2.7 \mathrm{~g} / \mathrm{dL}$ in $\mathrm{FDF}(\mathrm{P}<0.05)$.

The results relating to the blood properties showed that salinity changes affected to the oxygen binding factors, and its clearly related to the OC rate. Changes in $\mathrm{Ht}$ and $\mathrm{Hb}$ according to salinity found somewhat similarity in $\mathrm{Ht}$ from other study (Chang \& Hur, 1999; Chen et al., 1995; Houston \& Rupert, 1976). $\mathrm{Ht}$ and $\mathrm{Hb}$ values from this study were also compared to grey mullets $(30.5 \pm 2.9 \%$ and $8.0 \pm 1.5 \mathrm{~g} / \mathrm{dL}$ ) which was reported by Min et al. (2010). Some experimental groups had somewhat similar in $\mathrm{Ht}$ and $\mathrm{Hb}$ factors, but some experimental groups had lower results. Changes in blood factors caused by salinity on fish Channa punctatus was also reported by Dheer et al. (1986).

The results of biochemical properties of grey mullets' blood plasma also indicated that salinity changes in grey mullets clearly affected their blood factors. Some ion contents on grey mullets in FW environments were lower amount than that of grey mullets in SW. Almost 77\% of the salts in blood were sodium and chloride. The remainder was made up primarily of bicarbonate, potassium, and calcium. Sodium $\left(\mathrm{Na}^{+}\right)$, potassium $\left(\mathrm{K}^{+}\right)$, and calcium $(\mathrm{Ca})$ salts were critical for the normal function of heart, nerve, and muscle tissue (Wurts, 1998).

Salinity changes from SW to BW or FW which was lower amount of ions than that of SW caused the grey mullets became weaker and lower in their metabolism than before. Khodabandeh et al. (2009) observed golden grey mullets and concluded that the main ion content such as $\mathrm{Na}^{+}, \mathrm{Cl}^{\text {}}$, and $\mathrm{K}^{+}$were lower in line with the decreasing salinity. This result could be the main reason of the difference behavior in activity and $\mathrm{OC}$ according to salinity changes. To inhabit at low salinity or freshwater, fish need to replace salts lost through diffusion to the water and eliminate excess water absorbed from the environment (Wurts, 1998).

The results of OC and blood properties also showed relationship between $\mathrm{OC}$ and other blood properties parameters such as osmolality, cortisol, and glucose. The correlation can be found between $\mathrm{OC}$ and cortisol, while the osmolality and glucose were not clearly correlated to $\mathrm{OC}$ since the values were not significantly different (Table 9).

Salinity changes from SW to FW tended to decrease the $\mathrm{OC}$ of grey mullet and increased the cortisol levels inside the blood. However, salinity changes from FW to SW tended to increase the $\mathrm{OC}$ and decreased the cortisol levels. These results suggested that stress factors clearly affected to OC of grey mullets. At the stress conditions by salinity changes, these salinity differences result in modifications in OC and energy demands (Morgan \& Iwama, 1991). Cortisol was assigned to stimulate the liver gluconeogenesis and elevating blood sugar levels (Wedemeyer et al., 1990), which was related to the

Table 9. OC, osmolality, cortisol, and glucose levels of grey mullets Mugil cephalus in each experiment

\begin{tabular}{ccccc}
\hline Group & $\begin{array}{c}\text { OC } \\
\left(\mathbf{m g ~} \mathbf{~}_{2} / \mathbf{k g} / \mathbf{h}\right)\end{array}$ & $\begin{array}{c}\text { Osmolality } \\
(\mathbf{m O s m} / \mathbf{k g})\end{array}$ & $\begin{array}{c}\text { Cortisol } \\
(\mathbf{n g} / \mathbf{d L})\end{array}$ & $\begin{array}{c}\text { Glucose } \\
(\mathbf{m g} / \mathbf{d L})\end{array}$ \\
\hline SDS & $194.5 \pm 19.1^{\mathrm{c}}$ & $302.0 \pm 14.1^{\mathrm{a}}$ & $20.6 \pm 5.4^{\mathrm{a}}$ & $65.0 \pm 18.4^{\mathrm{ab}}$ \\
SGF & $164.6 \pm 17.2^{\mathrm{b}}$ & $323.5 \pm 17.7^{\mathrm{a}}$ & $154.6 \pm 44.6^{\mathrm{b}}$ & $42.0 \pm 2.8^{\mathrm{a}}$ \\
SDF & $95.5 \pm 37.1^{\mathrm{a}}$ & $311.5 \pm 9.2^{\mathrm{a}}$ & $316.2 \pm 21.1^{\mathrm{c}}$ & $62.0 \pm 4.2^{\mathrm{b}}$ \\
FDF & $167.9 \pm 22.2^{\mathrm{a}}$ & $314.5 \pm 40.3^{\mathrm{a}}$ & $40.2 \pm 21.1^{\mathrm{b}}$ & $46.5 \pm 4.9^{\mathrm{ab}}$ \\
FDS & $184.0 \pm 32.0^{\mathrm{b}}$ & $379.0 \pm 8.5^{\mathrm{a}}$ & $10.3 \pm 1.3^{\mathrm{a}}$ & $31.5 \pm 10.6^{\mathrm{a}}$ \\
\hline
\end{tabular}

Note: SDS, SGF, SDF, FDF, and FDS are the same abbreviations as in Table 1. Letters indicate significant differences between each experiment $(\mathrm{P}<0.05$, one-way ANOVA). 
fish osmoregulation ability. In other results, grey mullets exposed in low salinity did not change the osmolality levels, indicating that grey mullets was a good osmoregulator species. These results were similar with gulf killifish (Boily et al., 2007) and genus Fundulus (Griffith, 1974).

\section{CONCLUSION}

Salinity clearly affected the oxygen consumption and blood properties of grey mullets Mugil cephalus. Lowering salinity from seawater to freshwater decreased the oxygen consumption and causing mortality if the grey mullets transferred directly from seawater to freshwater without gradual salinity changes. Meanwhile, salinity change from freshwater to seawater increased the oxygen consumption of grey mullets. Furthermore, lowering salinity tend to increase the stress level of grey mullets. It mainly identified by the increase of cortisol levels during low salinity environment. Meanwhile, the stress level of grey mullets decreased with the increase of salinity. According to the information from this study, grey mullet rearing in freshwater might be applied for aquaculture development due to its osmotic adaptation ability.

\section{ACKNOWLEDGEMENT}

We thank Korea International Cooperation Agency (KOICA) for funding this study.

\section{REFERENCES}

Arnason, T., Magnadottir, B., Bjornsson, B., Steinarsson, A., \& Bjornsson, B.T. (2013). Effects of salinity and temperature on growth, plasma ions, cortisol and immune parameters of juvenile Atlantic cod (Gadus morhua). Aquaculture, 380-383, 70-79.

Beamish, F.W.H., \& Mookherjii, P.S. (1964). Respiration of fishes with special emphasis on standard oxygen consumption. II. Influence of weight and temperature on respiration of goldfish, Carassius auratus L. Canadian Journal of Zoology, 42, 161175.

Boily, P., Rees, B.B., \& Williamson, L.A.C. (2007). Vertebrate osmoregulation: a student laboratory exercise using teleost fish. Advances in Physiology Education, 31, 352-357.

Bjornsson, B., \& Olafsdottir, S.R. (2006). Effects of water quality and stocking density on growth performance of juvenile cod (Gadus morhua L.). ICES Journal of Marine Science, 63, 326-334.

Chang, Y.J., \& Hur, J.W. (1999). Physiological responses of grey mullets (Mugil cephalus) and nile tilapia (Oreochromis niloticus) by rapid changes in salinity of rearing water. Journal of Korean Fisheries Society, 32, 310-316.

Chang, Y.J., Jeong, M.H., Min, B.H., Neill, W.H., \& Fontaine, L.P. (2005). Effect of photoperiod, temperature, and fish size on oxygen consumption in the black porgy Acanthopagrus schlegeli. Journal of Fisheries Science and Technology, 8, 142-150.

Chen, G.R., Sun, L.T., Lee, Y.H., \& Chang, C.F. (1995). Characteristics of blood in common carp, Cyprinus carpio, exposed to low temperature. Journal of Applied Aquaculture, 5, 21-31.

Dheer, J.M.S., Dheer, T.R., \& Mabajan, C.L. (1986). Haematological and haematopoitic response to sodium chloride stress in a fresh water Channus punctatus. Journal of Fish Biology, 28, 119-128.

Duan, Y., Dong, X., Zhang, X., \& Miao, Z. (2011). Effects of dissolved oxygen concentration and stocking density on the growth, energy budget, and body composition of juvenile Japanese flounder, Paralichthys olivaceus (Temminck et Schlegel). Aquaculture Research, 42, 407-416.

Franklin, C.E., Johnston, I.A., Crockford, T., \& Kamunde, C. (1995). Scaling of oxygen consumption of Lake Magadi tilapia, a fish living at $37^{\circ} \mathrm{C}$. Journal of Fish Biology, 46, 829-834.

Griffith, R.W. (1974). Environment and salinity tolerance in the genus Fundulus. Copeia, p. 319-331.

Houston, A.H., \& Rupert, R. (1976). Immediate response of hemoglobin system of the goldfish, Cyprinus auratus, to temperature change. Canadian Journal of Zoology, 54, 1737-1741.

Iwama, G.K., Takemura, A., \& Takano, K. (1997). Oxygen consumption rates of tilapia in freshwater, seawater, and hypersaline seawater.Journal of Fish Biology, 51, 886-894.

Jeong, M.H., Kim, Y.S., Min, B.H., \& Chang, Y.J. (2007). Effect of fish number in respiratory chamber on routine oxygen consumption of black porgy Acanthopagrus schlegeli reared in seawater or freshwater. Aquaculture, 20, 121-126.

Khodabandeh, S., Moghaddam, M.S., \& Abtahi, B. (2009). Changes in chloride cell abundance, $\mathrm{Na}^{+}$, $\mathrm{K}^{+}$-ATPase immunolocalization and activity in the gills of golden grey mullets, Liza aurata, fry during adaptation to different salinities. Yakhteh Medical Journal, 11, 49-54.

Kim, I.N., Chang, Y.J., \& Kwon, J.Y. (1995). Pattern of oxygen consumption in six species of marine fish. Journal of Korean Fisheries Society, 28, 373-381.

Kim, S.J., Lee, Y.D., Yeo, I.K., Baek, H.J., Kim, H.B., Nagae, M., Soyano, K., \& Hara, A. (2004). Reproductive cycle of the female grey mullets, Mugil cephalus, on the coast of Jeju Island, Korea. Journal of Environmental Toxicology, 19, 73-80. 
Lovell, T. (1998). Nutrition and feeding of fish. Second Edition. Kluwer Academic Publications. Massachusetts, $271 \mathrm{pp}$.

Lyytikäinen, T., \& Jobling, M. (1998). The effect of temperature fluctuations on oxygen consumption and ammonia excretion in underyearling Lake Inari Arctic charr. Journal of Fish Biology, 52, 1186-1198.

Min, E.Y., Kim, Y.S., \& Kang, J.C. (2010). Dietary effects of lactic acid bacteria on growth, hematological and immune response of grey mullets, Mugil cephalus. Journal of Fish Pathology, 23, 343355.

Morgan, J.D., \& Iwama, G.K. (1991). Effects of salinity on growth, metabolism, and ion regulation in juvenile rainbow and steelhead trout (Oncorhynchus mykiss) and fall chinook salmon (Oncorhynchus tshawytscha). Canadian Journal of Fisheries and Aquatic Sciences, 48, 2083-2094.

Requena, A., Fernandez-Borras, J., \& Planas, J. (1997). The effects of a temperature rise on oxygen consumption and energy budget in gilthead seabream. Aquaculture International, 5, 415-426.

Saleh, M. (2008). Capture-based aquaculture of mullets in Egypt. p. 109-126. In Capture-based aquaculture. Global overview. FAO Fisheries Technical Paper No. 508. Lovatelli, A., \& Holthus, P.F. (Eds.). FAO. Rome, 298 pp.

Szczepkowski, M., Szczepkowska, B., \& Piotrowska, I. (2011). Impact of higher stocking density of juvenile Atlantic sturgeon, Acipenser oxyrinchus Mitchill, on fish growth, oxygen consumption, and ammonia excretion. Archives of Polish Fisheries, 19, 59-67.
Tsuzuki, M.Y., Strussmann, C.A., \& Takashima, F. (2008). Effect of salinity on the oxygen consumption of larvae of the silversides Odontesthes hatcheri and 0 . bonariensis (Osteichthyes, Atherinopsidae). Brazilian Archives of Biology and Technology, 51, 563567.

Turker, H. (2011). The effect of water temperature on standard and routine metabolic rate in two different sizes of Nile tilapia. Kafkas Universitesi Veteriner Fakültesi Dergisi, 17, 575-580.

Van Maaren, C.C., Kita, J., \& Daniels, H.V. (2000). Temperature tolerance and oxygen consumption rates for juvenile southern flounder Paralichthys lethostigma acclimated to five different temperatures. p. 135-140. In Spawning and maturation of aquaculture species: Proceedings of the twenty-eighth UJNR Aquaculture Panel Symposium. UJNR Technical Report No. 28. Tamaru, C.C.T., Tamaru, C.S., McVey, J.P., \& Ikuta, K. (Eds.). University of Hawai'i Sea Grant College Program. Hawai'i, 174 pp.

Wares, W.D., \& Igram, R. (1979). Oxygen consumption in the fathead minnow (Pimephales promelas Rafinesque), effects of weight, temperature, group size, oxygen level, and opercular movement rate as a function of temperature. Comparative Biochemistry and Physiology, 62, 351-356.

Wedemeyer, G.A., Barton, B.A., \& McLeay, D.J. (1990). Stress and acclimation. p. 451-489. In Methods for fish biology. Schreck, C.B., \& Moyle, P.B. (Eds.). American Fisheries Society. Maryland, 684 pp.

Wurts, W.A. (1998). Why can some fish live in freshwater, some in salt water, and some in both?. World Aquaculture, 29, 65. 
